\title{
A Legislação de Câmbios Sob o Aspecto Penal
}

\author{
IRALTON BENIGNo CAVALCANTI
}

A ais.

MATÉRIA de legislação de câmbics oferece um campo de observação interessante, quando vista de um ângulo muito particular: o aspecto penal de suas sanções.

Sendo a legislação de câmbio quase tôda ela de natureza regulamentar, o tema do regime jurídico-penal do contrôle de câmbios dịsperta interêsse e curiosidade pelo pouco que dêle se escreveu e se sistematizou, quer no Brasil, quer no estrangeiro. A razão talvez dessa quase indiferença dos juristas pátrios por um dos aspectos da legislação brasileira isolado e perdido no caudal legislativo dos tempos atuais, é que a legislação sôbre câmbios sendo de natureza temporária, já que transitório pelos seus próprios fins é também o regime de contrôle de câmbios, não desperta, cie um modo geral, a atenção dos que se achem envolvidos em tarefas diversas, estudando e sistematizando, retirando princípios gerais de leis novas que, de mais perto, envolvem os interêsses diretos dos povos.

Assim é que, pelo que pensamos, as manobras; expedientes, tôda a sorte de astúcia de que lançaram mão os comerciantes para fraudar o contrôle dos preços vindo a ferir diretamente a economia dos povos, passaram a constituir figuras delituosas cutônomas - os crimes contra a economia popular - enquanto que, no campo da legișlação brasileira de câmbios, todos os expedientes envolvendo fraudes ao regime de contrôle cambial do país, são apenas administrativamente puníveis, e as sanções, ainda que tìpicamente penais, conforme vamos demonstrar ho curso dêste trabalho, não ultrapassaram ainda o terreno das multas, não têm uma ncta infamante que as penas privativas de liberdade acarretam consigo.

Falamos de contrôle de preços, de crimes contra a economia popular como exemplos apenas, pois acidentalmente existe certa relação de similitude entre as situações próprias do contrôle de câmbios, e as existentes no campo do contrôle de preços, emanando ambos - de um fundo comum a economia dirigida.

\section{A INFRAÇÃO DE CÂMBIOS - ILÍCITO ADMINISTRATIVO}

O contrôle de câmbio é um dos instrumentos mais fortes e eficientes de politica econômica. As fraudes perpetradas alcançam prejuízos vultosos quando não descobertas e punidas. Tôda a coletividade sofre as conseqüências danosas dos desvios de divisas sob a forma fraudulenta, por assim dizer, 
criminosa, se os meios de contrôle não se mostrarem suficientes. As multas, as interdições, as penas infligidas aos recalcitrantes, embora tenham a função intimidativa própria das sanções penais, ainda constituem apenas e rigorosamente ilícito administrativo, cuja prática pode envolver a de atos catalogados como delitos autónomos pelo Direito Penal comum, mas que, pela alta técnica e sagacidade de seus autores não deixam vestígio documental capaz de conduzi-los às penas de prisão.

Sabemos que a matéria contém delicadas fibras e que, a considerarmos a potencialidade dos danos que podem advir das fraudes cambiais, de há muito o legislador brasileiro teria elevado à categoria de ilícito penal a prática de atos fraudatórios do contrôle de câmbios, cuja significação num regime de economia como a nossa e nos tempos atuais é bastante grande.

\section{A LEGISLAÇÃO DE CÂMBIOS E OS PRINCÍPIOS FUNDAMENTAIS DO DIREITO PENAL CLÁSSICO}

Vamos abordar, de modo sucinto, os diversos aspectos particulares que assumem os dispositivos de ordem penal na legislação de câmbio, tendo em vista principalmente os princípios fundamentais do direito penal clássico. Veremos que, em matéria de câmbios, de que o Estado detém o contrôle, uma das características constantes é a severidade das penas, se considerarmos as sanções previstas para as fraudes aos regimes de economia controlada em diversos paises. Em virtude de a legislação penal de câmbios existir por causa do contrôle pelo Estado, vamos começar examinando em que clima e debaixo de que orientação político-econômica se situa o Estado moderno, cuja atuação cada vez mais crescente marca o domínio da socialização do direito e, em particular, considerando-se as relações contratuais de câmbio, a publicização do direito privado.

\section{A LEGISLAÇÃO DE CÂMBIOS E O ESTADO MODERNO}

As conseqüências das duas grandes guerras, da crise de 1929-31, conduziram os Estados a caminhos diversos dos perseguidos nos tempos de domínio de uma política econômica condizente com as idéias filosóficas do individualismo jurídico e com a economia liberal. "Os Estados Modernos", como bem observam CARLos JáuREgui e José PIÑEIRo, "os Estados Modernos, qualquer que seja sua tendência política, revelem a característica comum de serem intervencionistas, sendo uma de suas mais conhecidas e significativas manifestações a que se refere à atividade econômica". (1)

Nas circunstâncies presentes, podemos dizer com SALVADOR ORIA, professor de Finanças na Universidade de Buenos Aires, que "Quando se fala do Estado se compreende, indubitàvelmente, como um sinônimo exato, que se fala do poder público. " $\mathrm{E}$ como se entende que por sua utilidade e aperfeiçoamento esta instituição é indispensável para o progresso social, pelo menos tal como está constituído, física, espiritual e moralmente o mundo contemporâneo, não se pode prescindir da noção concorrente dos serviços a serem

(1) Jáuregui, Carlos e PiÑeiro, Josè, Régimen penal del control de Câmbios, Eđiçốes Arayú, Buenos Aires, 1953, p. XVI. 
cumpridos em bem da sociedade ou da Nação que são sua parte viva e animade, para que se possam levar adiante serviços ou realizar atos benéficos para todos e não para um setor social ou para uma classe privilegiada como ocorria no passado". (2) Cada vez mais cresce o número de atribuições do Estado, cada vez mais se alastra o seu campo de ação, cada vez mais se ع cumulam e se avolumam os interêsses pedindo tutela jurídica e, considerandose a ordem apenas interna, os desequilíbrios econômicos das classes, que compõem o elemento humano do Estado, provocam a ação dêste visando a proteger os mais fracos contra os prepotentes e detentores da maior parte da riqueza.

\section{A FUNÇÃO ECONÔMICA DO ESTADO E A INICIATIVA PRIVADA}

Cabe assim assinalar-se, de passagem, a função econômica do Estado com relação à iniciativa privada. Segundo SALVADOR ORIA, "debaixo do regime econômico da escola liberal, a função do govêrno se limitou a proteger as emprêsas particulares ocupadas ccm o seu próprio desenvolvimento, evitando ou reprimindo os delitos contra as mesmas, as manobras ou ciladas que possam lesar seus direitos ou perturbar sua ação. O govêrno tem, assim, funções de "gendarme",... (3)

\section{CONSEQÜÊNCIAS DAS GUERRAS: O INTERVENCIONISMO}

As guerras, as crises, porém, obrigaram a atitudes diferentes por parte do Estado. Nem sempre, pelo vulto dos serviços ou pela sua própria finalidade, haveria de tocar à iniciativa privada o seu empreendimento. NELSON HUNGRIA, um dos mais eminentes penalistas pátrio, sintetiza nas seguintes palavras a atitude atual dos Estados: "A eccnomia liberal exige do Estado o máximo de abstenção no setor econômico. Ao Estado nada mais incumbe que uma atitude contemplativa em face da lei da oferta e da procura e da livre iniciativa individual". (4) Entretanto, "intervindo direta e militantemente na vida econômica, o Estado Novo não se limita a medidas de direito civil ou puramente administrativas recorre, também, ao expediente das sanções penais, que são a "ultima ratio" contra as vontades recalcitrantes". (5) Assim é que justifica êsse ilustre jurista brasileiro a reação do Estado contra os monopólios, afirmando que "no jôgo das fôrças econômicas, porém, interferem, não raramente, os tortuosc's processos do afarismo, os ardis da ávida especulação de indivíduos ou grupos, interrompendo-se o equilíbrio e frustrando-se a tendência para a normalidade". (6)

"A êsses expedientes perturbadores da vida econômica pode dar-se, de modo geral, o nome de monopólio". (7)

(2) Oria, Salvador, El Estado Arǵentino y la Nueva Economia, intervencionismo defensivo, Impressores Peuser S. A., Buenos Aires, 1954, p. 47.

(3) Oria, Salvador, op. cit., p. 15.

(4) Hungria, Nelson, Dos crimes contra a economia popular e das vendas a prestaçũo com reservas de domínio, Livr. Jacinto, Rio, 1939, p. 5.

(5) Ob. cit., p. 10.

(6) Obr. cit., p. 20.

(7) Op. cit., p. 20. 
A afinidade de que falamos entre o regime de contrôle de câmbios e o de preços, dêste surgindo figuras delituosas autônomas como, por exemplo, os crimes contra a economia popular, reside em que o intervencionismo estatal se reflete, em sua forma mais significativa, porque tende a procura do equilíbrio de sua própria balança de pagamentos, no contrôle das divisas estrangeiras. Com estas, advindas em grande parte da exportação de produtos nacionais, solve o Estado os seus compromissos. Põe-nas à disposição do movimento importador do país, com elas pagando as importações. Assume, pelo contrôle de câmbios, a posição de principal intermediário, a cujos cofres vão, em último lugar, ter destino as moedas estrargeiras pela obrigatoriedade de venda pelos bancos particulares de suas compras de cambiais de exportação - que, na linguagem bancária, se pode traduzir como repasse. Daí parece fácil aquilatar o que representam as violações às leis de contrôle cambial, o quanto se perturba a vida econòmica do Estado com as sonegações de câmbio, os desvios de divisas, os demais tipos de fraudes todos tendentes a retirar do Estado, para se concentrarem nas mãos de indivíduos ou grupos, as divisas desfalcadas por meios fraudulentos.

\section{A NOÇÃO DE DELITOS ECONÔMICOS}

CARlos Júuregui e José PiñEIro afirmam que "...tôda violação ao regime do contrôle de câmbios produzirá uma perturbação essencialmente econômica, e, em muito menor grau, financeira, podendo-se qualificar-se as transgressões como infrações ou delitos econômicos". (8)

Entre nós, JAYME LEONEL, escrevendo o que êsse autor modestamente chamou de um ensaio com referência à legislação cambial brasileira, e que representa em nossa literatura jurídico-penal um livro pràticamente isolado; afirmou que "...em matéria de política cambial ou de política comercial com o exterior, a intervenção do Estado, nos dias de hoje, é um fato patente e incontestável. "Quando os particulares se apartam da orientação fixada pela autoridade pública na legislação controladora desses atividades, causam êles, sem dúvida, uma perturbação essencialmente econômica e, em grau muito menor, financeira, pelo que aquêles prestigiosos juristas argentinos (CARLOS JÁUREGUI e JOSÉ PIÑEIRO) pretenderam construir uma classe especial de delitos, sob a denominação de Delitos Econômicos, compreendendo especialmente as transgressões dessa natureza". (9) Alusão também a delito econômico se encontra num livro de Frennand Charles Jeantet, intitulado Le code des prix et les principes fondamentaux đu droit pénal classique, em que êsse escritor comenta a lei francesa de 1940 que versa sôbre majoração ilícita.

Prefaciando a obra citada de JEANTET, um dos mais destacados juristas da França, Donnedieu DE VABRES, afirma que aquêle autor "veio a iluminar o traço mais original da legislação nova, a noção de delito econômico, que se caracteriza por uma reação contra a tendência à individualização da pena; o

(8) Jáuregui, Carlos e Piñeiro, Josì, op. cit, p. XVII.

(9) Leonel JAYMe, Contrôle de Câmbios - Regime jurídico penal, Jornal dơ Comércio, Rodrigues \&s Cia., p. 75. 
direito penal se torna, aí direito disciplinar; as exigências da repressão impõem um automatismo, um objetivismo renovado". (10)

\section{A NATUREZA PENAL-ADMINISTRATIVA DA LEGISLAÇÃO DE CÂMBIOS}

A natureza disciplinar que toma o direito penal no setor econômico faz lembrar a discussão doutrinária que se levantou em tôrno da natureza das normas de legislação penal de câmbios. CARLos Jáuregui e José PIÑEIRo afirmam que "sem maior esfôrço, se compreende que esta legislação é, em parte, direito administrativo, porém, suas raízes mais profundas se encontram no direito penal substantivo e processual. Mas devemos fazer notar que, modernamente, na doutrina e na jurisprudência se discute qual dos dois elementos - penal ou administrativo - que integram as legislações dêsse tipo, é o predominante. Uma corrente moderna, representada em nosso país, principalmente, por tratadistas de direito administrativo - afirma a existência de um direito penal administrativo com autonomia científica". (11) Não nos preocupando com a autonomia dêsse ramo do Direito Público, não nos parece, entretanto, desrazoável dada a natureza disciplinar do regime de contrôle de câmbios, que seus dispositivos de caráter penal se rubriquem como pertinentes a êsse ramo especial do Direito. pois que, como salientamos desde o início dêste trabalho, entre nós, pelo menos, ainda não rotulamos as infrações à disciplina econômica no setor de câmbios como crimes puníveis de acôrdo com as normas do Direito penal comum.

\section{A NATUREZA TİPICAMENTE PENAL DAS SANÇÕES}

As sanções, porém, são de natureza inegàvelmente penal, pois que as multas imputáveis no caso de violação às normas regulamentares não visam nem à reparação nem à indenização dos prejuízos sofridos, mas se dirigem aos indivíduos como verdadeiras ameaças de castigo. E' a função intimidativa e não de ressarcimento das normas de direito penal. A multa, assim, para as casos de infrações, não visa a cobrir o "quentum" dos danos à economia, visarn, sim, pelo temor que são capazes de infundir, a criar freios à cobiça que se manifesta sob tôdas as formas de fraudes. E' o enriquecimento rápido que preocupa um determinado número de indivíduos, agitados, psicològicamente inclinados à perpetração de delitos em que a intenção dolosa se evidencia pelo fim colimado: desviar da arrecadação do Estado uma quantidade de divisas capaz de torná-los, sùbitemente, muitas vêzes ricos. O Estado, que controla os câmbios estrangeiros, procura, através da multa, não o repristinamento de um "statuquo", mas a punição dos que infringirem a disciplina econômica. "Pouco se dá, no dizer de JAYME LEONEL, que a pena seja simplesmente pecuniária, imposta sob a forma de multa; o seu grau ou quantidade, conforme o mostramos, são devidos aos variáveis critérios de política criminal, quando não ao puro arbítrio do Estado".

(10) Apud Jeantet, op. cit., p. 12.

(11) Jáuregui, Carlos e Piñetro, José, op cit, p. XVIr. 
"A multa não tem zí o caráter reparatório, hipótese em que não constituiria pena. Ela é cominada, como dizem os autores franceses, à titre de châtiment, isto é, como castigo, punição, correção; em última análise, como pena". (12)

\section{O PAPEL DA MULTA}

Asume, assim, a multe, que tem caráter tìpicamente penal, lugar de destaque no chamado Direito penal administrativo, dentro de cujo âmbito se situa legislação penal de câmbios. O fim visado com a perpetração de ilícitos, por assim dizer, cambiais, que, ontològicamente, não diferem de qualquer cutro ilícito penal, é o lucro indevido. Observam Florian, SALtelli, Romino, Di Falco, Démogue citados por Wyme Leonel, que a multa, "nos delitos inspirados no lucro, tem atuação específica". Para DÉmogue, a multa é a pena típica contra os crimes de cobiça, porque atinge o lado sensível do delinqüiente". (13) Tanto existe no Direito penal comum como no especial. "No direito penal administrativo ela, de fato, é a mais frequiente". (14)

No caso do Brasil, a multa para os infratores do regime de contrôle de câmbios foi instituída, quendo da criação da Fiscalização Bancária, pela Lei n. ${ }^{\circ} 4.182$, de $13 / 11 / 1920$, com o fim de reprimir, prevenir e coibir o jôgo sôbre o câmbio, assegurando apenas as operações legítimas. A seguirmos CARLOS JÁUREgui è JOSÉ PIÑEIRo, a multa de câmbios, cuja finalidade é a manutenção de uma estrutura da qual dependem fins econômicos, é de natureza essencialmente repressiva, intimidatória. Não impcrta onde se esquadre ela: no direito penal comum, ou no Direito penal administrativo; isto não constitui o fundo da questão, a nosso ver. A êste respeito, esta multa é da mesma natureza que as que sancionam a especulação ilícita, o monopólio, ou as infrações às distintas leis de regulamentação da produção e do comércio". (15)

Ora, são bastante claras as palavras de CARLOS JÁUREgui e JOSÉ PIÑEIRO, vindo a corroborar o que pensamos a respeito da afinidkde existente entre o contrôle de preços e contrôle de câmbios em que predominam, no campo da política de preços, os fixados pela autoridade competente, no âmbito dos câmbios, os preços das divisas que a autoridzde monetária fixar para a compra e venda de cambiais, como ocorre entre nós com a Lei n. ${ }^{\circ} 1.807$, de $7 / 1 / 953$, onde se lê:

"Serão efetuadas por taxas fixadas pelo Conselho da Superintendência da Moeda e do Crédito, resultantes de paridade declarada no Fundo Monetário Internacional, as operações de câmbio referentes:

a) à exportação e à importação de mercadorias, com os respectivos serviços de fretes, seguros e despesas bancárias;

Daí haverem aquêles eminentes escritores argentinos introduzido, na legisiação penal de câmbios, a noção de dilitos econômicos igualmente cata-

(12) LEONEL JAYME, op. cit., p. 57.

(13) LEONEL JAYME, op. cit., p. 59.

(14) LeONEL JAYMe, op. cit., p. 59.

(15) Jáuregui, Carlos e Piñeiro, José, op. cit., p. 34. 
logados por JEANTET entre os definidos como, por exemplo, majoração ilícita. Em relação a êste delito, JEANTET observa que se trata de um delito material, “...é, antes de tudo, a perturbação econômica que é preciso prevenir". (16)

\section{A LEGISLAÇÃo DE CÂMBIO E A ECONOMIA DIRIGIDA. CONSEQÜÊNCIA}

Assentado que, de acôrdo com a natureza da sanção prevista para os casos de transgressão aos preceitos da regulamentação de câmbios, a multa não tem caráter de ressarcimento ou de reparação de danos, mas intimidatório, punitivo, o que vale situar a legislação penal de câmbios como compreendida no direito penal administrativo, vamos agora tratar essa parcela de direito público, tendo em vista os regimes de economia dirigida e as conseqüentes derrogações por que têm de passar os princípios fundamentais do direito penal classico.

Para prosseguir na orientação de idéias que vimos desenvolvendo ao longc dêste artigo, sempre que nos pareça oportuno trataremos paralelamente a matéria de derrogações dos princípios clássicos do Direito penal, quer no campo do contrôle de preços, quer no de divisas, para isso nos valendo das lições de FERnAND Charles JEANTET e ANDRÉ Vitu, um e outro bastante categorizados como fontes de autoridade. O próprio JEANTET intitulou sua obra como o Código dos Preços e os princípios fundamentais do direito penal clássico. ANDRÉ VITU, incumbicio de apresentar um estudo sôbre a regulamentação dos câmbios o Direito Penal, publicou um excelente trabalh', que constitui parte da obra Le Controle des Changes - ses répercussions sur les irıstitutions juriáiques, estudo de Direito comparado sob a direção do Professor Joseph HAMEL, em Paris.

\section{O PRINCíPIO DA LEGALIDADE DOS DELITOS E DAS PENAS. A LEI PENAL EM BRANCO}

O ponto que mais nos impressionou é o problema da legalidade, isto é, o quc representa uma garantia dos direitos individuais contra o arbítrio do legislador e do juiz, e uma das maiores conquistas da civilização - o princípio da legalidade dos delitos e das penas - que deve intransigentemente ser defendido nos países de Constituição como a nossa. Numa matéria onde a fraude é freqüiente, onde a descrição dos delitos debaixo da mais rigorosa aplicação da regra nullum crimen sine lege, que o nosso Código Penal logo nu art. $10^{\circ}$ incorpora, dizendo que "não há crime sem lei anterior que o defina. Nem pena sem prévia cominação legal", não houvesse delegação de poderes co Executivo para, verdadeiramente quase legislando, pudesse abarcar tôdas as formas de expedientes utilizados para fraudar-se o contrôle de câmbios, e ver-se-ia pràticamente uma grande parte de infrações sem remédio, dada a demora necessária na feitura das leis pelo Congresso. Mas, anima-nos o fato de podermos afirmar que pode e deve subsistir o princípio da legalidade. Apenas tendo em vista a mutabiliảade das circunstâncias, visto que além de

(16) Jeantet, Charles, Fernand, op, cit., p. 64. 
ser excepcicnal a legislação de câmbios, ccracterística peculiar observada por CARlos JÁuregui e José PiÑEIRo, derivada, segundo êsses escritores, do fato de a legislação de câmbios ter "... nascido em circunstâncias excepcionais, provocadas por anomalias nas condições ambientes econômicos e financeiras", (17) além de excepcional, assume a legislação de câmbios outro caráter também peculiar: a variabilidade. Esta, conforme pensam os mencionados juristas argentinos, teria sido "... a razão principal levada em conta ao sancionar-se o art. 17 da Lei n. ${ }^{\circ} 12.160$, claro exemplo de lei penal em branco ou aberta strictus sensu. (18) O artigo 17 da Lei Argentina n. 12.160 diz que "as multas a aplicar-se em casos de infrações ou falsas declarações, de conformidade com a regulamentação ditada pelo Poder Executivo, não poderão exceder do décuplo da operação realizada". E o art. $10^{\circ}$ do Decreto n. 12.647 daquele país estatui que "Serão sancionadas com a penalidade do art. 17 da Lei n. ${ }^{\circ} 12.160$, as ações ou omissões que direta ou indirețmente violem as disposições sôbre câmbios, e em especial as seguintes: “... Para Carlos JÁUREguI e José PIÑEIRO, os artigos supramencionados têm a natureza de leis penais em branco. "O art. 17 citado só descreve uma infração: "a falsa declaração", e delega ao Poder Executivo a faculdade de tipificar outras transgressões. Ademais, o art. $1^{\circ}$ do decreto comentado contém uma nova norma em branco, tois delega ao organismo que dita as normas sôbre câmbio (Banco Central) a criação de novas e infinitas infrações". (19) Com o fim de tornar mais clara a exposição, invocamos os ensinamentos de BASILEU GARCIA, emérito penalista pátrio, a respeito da conceituação da lei penal em tranco. Diz êsse autor que "por vêzes, a lei penal, ao conceituar a infração, reporta-se a textos extrapenais, em vigor ou porvindouros, de cujo conteúdo ficam a depender os contornos e a própria existência da figura delituosa. Aí temos a chamada lei penal em branco, modalidade que, pela sua progressiva adoção, assume uma importância que de certo modo cerceia o império do princípio nullum crimen. Sim, porque surge tão difusa e imprecisa, em alguns casos, a complementação da norma penal, e obriga a tão intrincadas averiguações para positivar-se a existência ou não do crime, que aquêle dogma lundamental decai do seu valor como garantia contra imputações especiosas ou arbitráries". (20) Menciona como exemplo de lei penal em branco, dentro da legislação especial, o crime previsto no art. $2 .^{\circ}$, n. ${ }^{\circ}$ VI, da Lei n. ${ }^{\circ} 1.521$, de 26 de dezembro de 1951 (infração à tabela de preços).

ANDRÉ VITU, tratando da lei penal e seu alcance em matéria de direito cambic1, observa que "um problema delicado surge desde o início. Pode-se perguntar se, numa matéria onde a fraude é frequiente e onde o Estado é obrigado a impor com firmeza as diretrizes de sua política econômica, o legislador não cedeu à tentação de afestar, pelo menos implìcitamente, o princípio fundamental nullum crimen, nulla poena sine lege, facultando aos juízes e às autoridades administrativas um poder, mais ou menos arbitrário, para cata-

(17) Op. cit., p. XVIII.

(18) Jáuregui, Carlos e PiñeIro, José, cp. cit., p. XVIII/XIX, Introdução.

(19) Op. cit., pp. 41-42.

(20) Garicia, Basileu, Instituições de Direito Penal, edição de Max Limonad, 1954, p. 154 . 
logar e reprimir as infrações à regulamentação dos câmbios. Em conseqüência, o legislador não delegou às autoridades administrativas o cuidado de prever, em todos os seus pormenores, a regulamentação penal, limitando-se a traçar algumas diretrizes gerais bastante vagas!" Acrescentou ANDRÉ VITU que se observa “...na França e em outros países, que o legislador tende a abdicar uma parte de seu poder entre as mãos da administração e do juiz. Sensível sobretudo em matéria de direito penal financeiro e econômico, essa tendência se explica pela amplitude de uma tarefa de direção da economia que ultrapassa os meios técnicos do legislador: êste não pode agir bastante ràpidamente para envolver ao mesmo tempo todos os problemas infinitamente complexos e mutáveis apresentados pela economia". (21) Em matéria de preços igualmente, JEANTET, estudando a lei francesa de 1940 diz que “...é sobretudo o cutáter de infração à disciplina, econômica que forma o sedimento essencial das regras particulares contidas nessa lei, inspirada pelo sôpro autoritário: o princípio de legalidade subsiste, mas cada lei é apenas uma ordem que os dirigentes são chamados a modificar para agir sôbre os acontecimentos, a tunção legislativa estendo hoje subordinada à função governamental". (22)

E' bem verdade que a obra de JEANTET foi escrita na época da guerra. As leis que o motivaram eram leis de emergência. Não pensamos, contudo, que us fatos por êle observados deixem de ter grande valia, pois que o contrôle de câmbios também é fruto das guerras e, se perdura, é porque os fatos excepcionais que o motivaram ainda subsistem a tudo indica que o seu desaparecimento não se dará num futuro muito próximo.

A verdade é que, tratando-se de matéria em que a fraude pela sua intensidade reflete o espírito astucioso do agente, a finura e a sagacidade exigidas para a consumação de atos contrários à lei e que, pela aparência revestida de tôdas as formalidades, fingem cumpri-la, justifica-se uma fórmula genérica abrangendo quaisquer expedientes, envolvendo por todos os lados os ardis e manobras comissivos por açäo ou omissão no intuito de fraudar o objetivo visado pelo legislador.

Eleve-se à categoria de ilícito penal a prática de atos fraudatórios do contrôle de câmbios já que, como điz NELSON HungRIA, “... seria impossível uma exaustiva fórmula casuística na seleção da fraude penal, ao juiz é que cabe, necessàriamente, apreciar se êste ou aquele caso concreto se enquadra na fórmula genérica da lei penal".

Já vimos que a lei penal em branco representa um limite à aplicação absoluta do principio "nullum crimen nulla poena sine lege", carreando para textos extrapenais a descrição minuciosa da entidade delitiva; igualmente vimos que o legislador argentino a utilizou para a repressão das fraudes cambiais; que, em matéria de fraude penal é impossível uma rigorosa descrição dos casos que podem ocorrer; que deve e pode subsistir a regra nullum crimen nulla poena sine lege com a elevação a ilícito tìpicamente penal de qualquer infração à legislação de contrôle de câmbios, mesmo porque, como દinda justifica Nelson Hungria, "não procedem os embargos de TOLOMEI e do nosso Galdino Siqueira, que se arrepiam ante a idéia do "arbítrio judicial" e até invocam o nullum crime, nulla poena sine praevia lege poenali. $\mathrm{Na}$ incriminação, sustenta êsse eminente jus-penalista, da lesão patrimonial per iraudem, existe a lex praevia, mas, como esta tem de adotar uma fórmula de 
contornos amplos, pois seria vã a tentativa de uma casuística rigorosa, não pode deixar de ser confiado ao juiz, na sua própria função específica de jus conditum dicere, o oportuno ajustamento dessa fórmula aos casos ocorrentes". (24)

\section{JUSTIFICATIVA DA LIMITAÇȦO AO PRINCÍPIO DA LEGALIDADE}

A limitação ao princípio da legalidade dos delitos e das penas se justifica pela interdependência existente, em matéria de contrôle de câmbios e direito penal, entre os ditames da economia dirigida e a sua necessária influência derrogatória de princípios clássicos de direito penal quando êste vise a tutelar a ordem econômica. Entrelaçam-se dêsse modo, indissolùvelmente, a Economia e o Direito e, em proteção daquela, o Estado erigiria a ilícito penal a conduta daqueles para quem a multa aplicada apenas no campo administrativo não foi suficiente para intimidá-los. Foi o que fêz a Argentina para os casos de reincidência e concurso de infrações. Foi o que fizeram inúmeros outros países em tutela de sua economia. Não poderia ser de outro modo, pois que, como ensina ANDRÉ VITU, "um traço característico da época moderna é a influência crescente do Estado sôbre tôdas as manifestações da atividade humana. Conseqüências das crises e das guerras, uma economia nova nasceu, jırigida pela autoridade pública, que exerce um contrôle estreito sôbre os diversos aspectós da vida econômica:...."

A economia dirigida, com efeito, tem contribuído largamente para estender o domínio do direito penal, desmentindo assim a afirmação de IHERING, segundo a qual "a história da p̣ena se resume em uma abolição constante". (25)

Acrescenta êsse autor que "...esta legislação penal nova trouxe um atentado sensível às regras clássicas do direito penal e constitui um probilema apaixonante o de seguir a influência da economia dirigida sôbre os princípios fundamentais da repressão..." (26) Assume, assim, a legislação penal de cämbios um particularismo proveniente do dirigismo econômico.

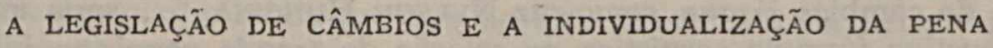

Do mesmo modo que sofre a regra nullum crimen, nulla poena sine lege derrogações, quando, excepcionalmente, existe a necessidade de uma lei penal em branco, também o princípio da individualização da pena, isto é, a faculdade que tem o juiz de fixar a pena entre um mínimo e um máximo, de acôrdo com o grau de culpabilidade do agente e as circunstâncias objetivas, em parte se derroga. E' que a infração ao contrôle de câmbios, assim como a violação ao contrôle de preços, deverá ser um delitu material. No dizer de JEANTET,

(21) VITU, ANDRE, in op. cit., p. 78.

(22) JEANTET, op. cit., p. 107.

(23) Hungria, Nelson, Hoffbauer, Fraude Penal, Ed. A. Coelho Branco Filho, 1934, p. 31.

(24) Hungria, Nelson, Fraude Penal, já cit., p. 32.

(25) VIYU, ANDRÉ, op. cit., p. 72.

(26) VITU, ANDRÉ, op. cit., p. 74. 
o crime de majoração ilícita é "....antes de tudo um delito material; é, em primeiro lugar, a perturbaç̧ão econômica que é preciso prevenir! (27) "A perturbação material faz presumir a intenção... Isto explica o caráter particular da individualização em matéria de preços: em um único sentido ela é orientada para agravação". (28)

Observe-se que, igualmente, em matéria de câmbios, o que, em parte, singulariza a sua legislação penal é, no dizer de ANDRÉ VITU, "... o lugar importante reservado às sanções penais e a severidade destas. E' evidente, acrescenta êsse jurista, que teria sido em vão esperar dos indivíduos uma obediência incondicionada a uma regulamentação que modificava profundamente os quadros jurídiccs dentro dos quais, até então, vinha se desenvolvendo o comércio internacional e que, por isso mesmo, abalava tendências de espírito ainda fortemente impregnadas de liberalismo". (29)

A individualização da pena, segundo DONNEDIEU DE VABRES, está estreitamente ligada ao problema dos delitos econômicos. Êstes se caracterizam "... por uma reação contra a tendência à individualização da pena; o direito penal aí se torna direito disciplinar; as exigências da repressão reclamam um automatismo, um objetivismo renovado". (30) Enquanto DoNNEDIEU DE VABRES fazia essa apreciação com referência ao livro de JEANTET, vale dizer, com relação à matéria de contrôle de preços, ANDRÉ VITU, analisando a natureza do direito penal de câmbios, assinala que "...êsse direito não é apenas severo, tende igualmente a ser objetivo: as infrações, muito freqüentemente, são de ordem exclusivamente material: a intenção criminosa raramente é levada em conta como um elemento constitutivo necessário". (31)

No dizer de JEANTET, " . . o princípio da individualização da pena é respeitado, mas não deve servir a elidir as prescriçöes imperativas que impõe a disciplina econômica". (32) Essse mesmo autor observa que "se pode conceber uma sanção administrativa das infrações materiais, e uma repressão judiciária das que denotem uma mentalidade perigosa. A sanção penal viria, eventualmente, acumular-se com a sanção disciplinar,...". (33)

"Essa distinção, segundo ainda JEANTET, é justificada pelo caráter profundo da infração econômica; ora delito artificial que apenes merece uma sanção automática, puramente intimidativa, não infamante "ne peccetur", ora delito natural, delito astucioso que denota uma mentalidade anti-social, e que merece uma sanção infamante, "quia peccatum". (34)

Acreditamos que o caráter de delito material que teria de assumir qualquer infração à legislação cambial, fàcilmente se explicaria porque, conforme já fizemos notar durante esta exposição, a entidade criminal dentro

(27) JeAnTET, op. cit., p. 64.

(28) JeAntet, op. cit., p. 64.

(29) VITU, ANDRÉ, op. cit., p. 75.

(30) VABres de DonnedieU, in op. cit., p. 12.

(31) VITU, ANDRÉ, op, cit., p. 76.

(32) JEANTET, op. cit., p. 107.

(33) JEANTET, op. cit., p. 110.

(34) JeAnteT, op, cit., p. 110. 
de cujos contornos se confina a prática contrária ao regime de contrôle de câmbios, é a fraude. Esta modalidade da conduta humana vai de gradação em gradação. Desde a "parva calliditas", que no dizer de NELson Hungria, "... se abriga à sombra de uma proclamada "naturalis licentia decipiendi"(35) até a maǵna calliditas, a fraude perigosa, justificativa dos crimes de estelionato e outros. Diz Nelson Hungria que a preocupação da forma jurídica pode ser, às vêzes, indício de mais requintada finura do agente, ou, precisamente, - veículo da fraude perigosa. (36)

Quer dizer de quem burla, apesar de tôdas as cautelas do Poder Público, o regime de contrôle de câmbios, declarando falsamente em documentos de existência imprescindível para a realização de operação cambial, com o fim de obter uma margem de divisas em detrimento do Estado? - A fraude anda inseparàvelmente ligada ao dolo. Este se presume naquela "juris et de jure". Daí a natureza de delito material que assumiria qualquer infração ao contrôle de câmbios através de fraude. ORTOLAN, citado por NELSON HUNGRIA, afirma que "...todo indivíduo deve agir segundo a prudência, a habilidade e a vigilância comuns no curso dos negócios, e sòmente quando tais cautelas resultem ineficazes, por isso que as supera a atividade rebelde ao direito, é que nesta se identifica a fraude penal". (37) O contrôle de câmbios rţıurta de uma série de medidas, de formalidades e expedientes utilizados pelo Estado com os fins de fiscalização da atividade particular no que diz respeito ao comércio exterior. O Estado fiscaliza, dêsse modo, o intercâmbio comercial já que êle, também, será parte nas negociações de câmbio. Numa operação de exportação ou importação de mercadorias, no Brasil, por exemplo, a operação de câmbio se realizará obrigatòriamente pela taxa do mercado oficial, vale dizer, pela taxa que o Poder Público tiver fixado. O Banco do Brasil, através de suas carteiras com funções delegadas do Poder, é que figura como último cumprador ou vendedor da moeda estrangeira. As declarações falsas, que fizerem exportadores ou importadores visando a sonegação de divisas, representam desvios da moeda estrangeira em detrimento do Estado.

Que dizer, por exemplo, da conduta fraudulenta de um grupo de individuos constituídos em uma firma exportadora de determinado produto brasileiro, que, através de declarações falsas na documentação exigida para a comprovação da legitimidade do negócio, conseguem evadir parte ou mesmo a totalidade da cobertura cambial da operação? Parte ou a totalidade da mceda estrangeira que viria a tornar-se, normalmente, capital disponível do Estado para aplicação na cobertura de importações essenciais ou não à economia brasileira, essim como para solver seus compromissos junto ao exterior, se desvia e fica no estrangeiro à disposição dos fraudadores. Não vemos por que não tenha caráter perigoso a astúcia engenhosa dos que fraudam o regime de contrôle de câmbios. Se se mede a periculosidade da fraude penal pela idoneidade dos meios empregados para ludibriar a boa fé e as diligências habituais da vítima, não vemos por que não constitua ilícito penal pròpriamente dito a fraude cambial.

(35) Hungria, Nelson, Fraude Penal, já cit., p. 14.

(36) Hungria, Nelson, op. cit., p. 40.

(37) Apud Hungria, Nelson, op. cit., p. 38. 
Já vimos que a multa para os casos de infração à legislação de câmbios não tem caráter reparatório, mas intimidativo, tìpicamente penal. Não se visa com ela, conforme já dissemos anteriormente, a repristinação de um "statu quo", mas a repressão de violações à disciplina econômica. E' um passo apenas para elevá-la a ilícito punivel com as penas privativas de liberdade.

"Merkel, Notaristefani e Puglia sustentam que a punibilidade da fraudo depende de uma condição: a impraticabilidade da "restitutio in pristinum" ou da reparação do dano". (38) Exemplificamos, para clareza maior do raciocínio que, falseando a verdade, uma firma pode desviar do Estado uma quantidade de divisas, digamos dólares, bastante grande, seja "ad argumentandum" declarando um preço maior para a mercadoria importada. O Estado que, em última análise, é quem remeterá, de acôrdo com o regime de contrôle de câmbios vigente, a cobertura, enviará mais dólares que o necessário para pagar a importação. Permanecerá, assim, no exterior à disposição do importador brasileiro, uma diferença em dólares que êle utilizará transferindo-a a taxas mais favoráveis e em prejuízo do Estado. A repristinação do "statu quo" é inteiramente impossível. Os dólares evadidos não se rєcuperarão e a perturbação econômica efetivamente se deu, pois que o Éstado perdendo o contrôle das divisas, enviou para o estrangeiro mais moeda que o suficiente para cobrir a importação. Deixou, assim, de aplicar em outras operações a quantidade de moeda sonegada. Perdeu a disponibilidade que o conluio de indivíduos ou de firmas inescrupulosas conseguiu desviar com um comportamento típico de fraude penal.

Baseando-nos em NeLsON HUNGRIA, procuramos aproximar o máximo possível a fraude cambial da penal e, em confirmação do que vimos sugerindo neste trabalho, citamos o seguinte trecho daquele preclaro penalista: "...há quase sempre fraude penal quando, relativamente idôneo o meio iludente, se descobre, na investig̨ção retrospectiva do fato, a idéia preconcebida, o propósito "ab initio" da frustração do equivalente econômico". (39)

Imagine-se a hipótese em que um importador brasileiro consegue, por meios fraudulentos, a evasão de divisas para o exterior, forjando documentos comprobatórios da importação que jamais se realizou. Não se trata, no caso, de evasão parcial de cobertura, mas de desvio completo de divisas. O importador desembolsa em cruzeiros junto ao Banco interveniente da operação uma quantia suficiente para cobrir o valor da mercadoria importada e demais encargos. O Banco intermediário transfere, através de um repasse, ao Banco do Brasil o valor dessa operação, por ocasião da liquidação dos contratos de câmbio. Vende por assim dizer, ao Estado, no mercado oficial, a moeda estrangeira. Se a importação foi simulada, nada efetivamente se importou. Bem algum veio a atingir pôrto brasileiro, $e_{x}$ no entanto, a moeda estrangeira se evadiu através de um processo engenhoso, de uma maquinação ardilosa e ousada, sem que o Estado tenha fôrça suficiente para impedir o envio da cobertura, pois que, a tal ponto chega a astúcia dos fraudadores, que a modalidade da operação torna obrigatória a remessa. Se tôdas as precauções do Estado culminaram como insuficientes para conter a fraude que, no caso,

(38) Apud Hungria, Nelson, Fraude Penal, p. 40.

(39) Hungria, Nelson, op. cit., p. 44. 
se reveste de uma periculosidade gritante, por que não caracterizar como ilícito penal uma infração dessa natureza?

Antes que se alegue que a forjadura do documento comprobatório da importação já constitui figura delituosa autônoma, argumentamos que se isso é necessário para o desvio da totalidade da cobertura, não o é, evidentemente, pæra parte dela. Tôda a documentação, nesta última hipótese, é verdadeira, constituindo a fraude num falsamento da verdade. A tomarmos o exemplo da França, qualquer infração à regulamentação dos câmbios, sem distinção, é declarada fato punivel penalmente. (40) $\mathrm{E}$ ' que em matéria de fraude, como assinala NELSON HuNGRIA, a lei penal é inevitàvelmente genérica. (41)

\section{A INFRAÇÃo DE CÂMBIOS E A CULPABILIDADE DO AGENTE. RESPONSABILIDADE PENAL DAS PESSOAS JURÍDICAS}

Visto o problema sob o aspecto da individualização da pena, a qual sofre derrogações em se tratando da legislação penal de câmbios, já que os princípios clássicos de moderação se substituem pela severidade da pena e o subjetivismo do direito penal clássico cede lugar a um objetivismo oriundo da ecònomia dirigida, dando à infração à regulamentação de câmbios a natureza de delito material, em cuja caracterização o dolo deve ser presumido pcr lei juris et de jure, em virtude da modalidade fraudulenta com que se consuma, vejamos agora em que consiste mais uma derrogação dos princípios clássicos do direito penal no tccante à culpabilidade.

E' relativamente à responsabilidade das pessoas morais, dos entes coletivos, que se observa a tendência geral do direito penal econômico e financeiro de conduzir até êles a responsabilidade penal. Derroga-se, dêsse modo, a regra clássica "Societas delinquere non potest".

O tema da responsabilidade penal das pessoas jurídicas é um tema bastante discutido em doutrina. "A responsabilidade penal continua a ter por fundamento, diz-se na exposição de motivos do Código Penal Brasileiro, a responsabilidade moral, que pressupõe no autor do crime, contemporâneamente à ação ou omissão, a capacidade de entendimento e a liberdade de vontade..." Prevalece em alguns países a regra de que "no máximo o ente moral pode ser civilmente responsável por seus prepostos delinqüentes". (42) Em outras legislações, se consagrou “... a responsabilidade penal das pessoas morais, pelo fato das ações delituosas de seus órgãos em matéria de câmbios". (43) Para a generalidade dos países, a disposição citada acima “...é excepcional e traduz ao mesmo tempo uma tendência à severidade em matéria econômica e um movimento para a admissão geral, sôbre 0 plano penal, da responsabilidade dos entes coletivos. E' claro que, de qualquer modo, sòmente as multas e as confiscações, com exclusão de tôda pena privativa ou restritiva de liberdade, são aplicáveis às pessoas morais". (44) A matéria enfeixa um

(40) V. a respeito VITU, ANDRÉ, in op. cit., p. 84.

(41) V. Hungria, Nelson, Fraude Penal, p. 32.

(42) VITU, ANDRÉ, in op. cit., p. 89.

(43) VITU, ANDRÉ, in op. cit., p. 90.

(44) VITU ANDRÉ, in op. cit., p. 90. 
campo de batalha em que, de um lado, eminentes penalistas continuam defendendo a absoluta validez do princípio Societas delinquere non potest, de outro, não menos preclaros escritores, sustentam a tese contrária, estendendo aos entes coletivos a capacidade de delinqüir.

CARlos Jáuregui e José Piñeiro afirmam que “... toca um dos pontos nevrálgicos do direito penal: o da responsabilidade penal das pessoas jurídicas". (45) Entretanto, apesar da opinião em contrário de penalistas da envergadura de Sebastian Soler, Eusebjo Gómez e Luiz Jiménez de Asúa, "... No campo do direito positivo de nosso país, acrescentam aquêles juristas argentinos, parece avançar cada dia mais a tese da responsabilidade penal das pessoas jurídicas". (46)

O problema vem de que as pessoas jurídicas, de acôrdo com o direito civil, não têm capacidade própria, apenas agem no campo do direito debミixo de representação. O crime e, em consequiência, a responsabilidade penal baseada na responsabilidade moral fundamentada na "capacidade de entendimento e na liberdade de vontade", não poderia, assim, ser cometido por pessoa desprovida de aptidão volitiva. Não haveria, dêsse modo, imputabilidade. Imputar-se à pessoa jurídica a conduta delituosa seria o mesmo que afirmar, em direito penal, uma responsabilidade objetiva ou sem culpa.

Ora, "no conceito de delito, foi incluído o elemento culpabilidade. Para ser punida, a ação humana deve ser culpável - poder-se atribuir à culpa (latu sensu) do seu autor". (47) E se "o dolo e a culpa pressupõem indispensáveis condições psíquicas" (48) como atribuí-los a pessoas juridicas? São critérios biopsicológicos que conduziram o legislador à estruturação do problema da imputabilidade e, em decorrência desta, o assentamento da responsabilidade penal. Pode-se, entretanto, obviar as dificuldades que apresenta o tema com o estabelecer-se a responsabilidade criminal dzs pessoas jurídicas, tendo em vista a sua natureza de ente ideal e não deixar de imputar-1hes a prática de delitos porque não são pessoas do mundo físico como nós, capazes de se autodeterminarem. E' mais uma questão de preconceito e de apêgo às tradições do individualismo do que uma dificuldade de ordem prática intransponível. Parecem muito fortes os argumentos dos que sustentam a irresponsabilidade penal das pessoas jurídicas, mas a realidade é que não resistem a uma observação mais profunda. Haveria mesmo, dentro da teoria da representação, que rege a atividade das pessoas jurídicas, lugar para estender-se até elas responsabilidade penal. As pessoas coletivas são dotadas de vontade, ainda que entes de constituição ideal apenas. A vontade deliberada de seus representantes é a sua própria vontade, coincidente cu não com a de todos os membros.

Dotadas, assim, de uma vontade própria, capazes são, portanto, de consciente e livremente deliberar. Podem, pois, com seus atos ofender a ordem penal. Podem tornar-se, portanto, como realidades sociais que são, temíveis e perigosos agentes de perturbação da ordem social e econômica.

(45) Jáuregui, Carlos e Piñeiro, José, op. cit., p. 72.

(46) JÁuregui, Carlos e Piñeiro, José, op. cit., p. 73.

(47) Garcia, Basileu, op. cit., p. 323.

(48) Garcia, Basileu, op. cit., p. 323. 
AFONSO ARINos DE MELo Franco, em tese excelente que apresentou à outra Congregação da Faculdade de Direito da Universidade do Rio de Janeiro, tratou com inexcedível brilho o tema da responsabilidade penal das pessoas jurídicas. Observa êsse ilustre jurista que "...quando as civilizações atingem períodos em que predominam as tendências coletivistas, as diversas modalidades de pessoas jurídicas, públicas ou privadas, adquirindo importância e capacidade de ação, tornam-se, em razão dessa mesna fôrça, ameaçadoras e lesives aos interêsses alheios aos seus. Como conseqüência inevitável disso aparece logo a reação dos Estados, procurando limitar-1hes as atividades, e surge, como resultado igualmente natural, a inclinação da doutrina científica, no sentido de considerar, na pessoas juridicas, possíveis agentes de infrações penais". (49) São, por conseguinte, de acôrdo com o seu comportamento, capazes de delinqüir, de agir em desconformidade com a ordem penal, infringindo-lhe os preceitos pela prática de atos antijurídicos e lesivos do interêsse alheio. Sem prejuízo da responsabilidade pessoal dos seus representantes, podem e devem ser-lhes cominado penas. No caso particular de infrações ao contrôle de câmbios, em que a prática envolvente é, de um modo geral, a fraude, não se trata, pois, de estabelecer-se responsabilidade penal sem culpa (latu sensu), pois que esta nas fraudes é elemento essencial.

Assim é que contornou o legislador argentino, conforme ensinamento de CARlos JáuREgui e José PIÑEIRo, a dificuldade, por isso que "A lei pode estabelecer situações das quais surjam objetivamente responsabilidades penais, mas quando isto sucede é porque a culpa se presume". (50)

Assim é que as leis argentinas de repressão à especulação ilícita, para citarmos exemplos de contrôle de preços, estabeleceram que, sem prejuízo da responsabilidade pessoal dos autores, a pessoa jurídica se submeterá a processo. "Nos casos de condenação de uma pessoa jurídica, associação ou sociedade, se poderá impor como sanção complementar a perda da personalidade e a caducidade das prerrogativas que the tiverem sido concedidas". (51) Isto que se disse com respeito à especulação ilícita, também é válido para os casos de repressão aos monopólios, tendo a lei argentina estabelecido que, quando "...o fato resulte cumprido em nome, com o auxílio ou em benefício da pessoa ideal", esta é solidária e penalmente responsável (52) Os citados juristas argentinos concluem que "como não se pode admitir que exista responsabilidade penal sem culpa, esta só pode surgir de circunstâncias estabelecidas na 1ei '. (53) O fato é que a economia dirigida rompe, de certo modo, com os pustulados do Direito Penal clássico e, considerando-se a matéria de contrôle dc preços, cuja afinidade com o contrôle de câmbios se estabelece pela simples inspeção que se faça num mercado de câmbio de taxas oficiais, o discutido princípio da responsabilidade penal das pessoas jurídicas foi introduzido na legislação argentina em matéria tributária, no contrôle do comércio de carnes,

(49) Melo Franco, A. A. DE, Resp. criminal das Pessoas Jurídicas, Graf. Ypiranga; Rio, 1930, p. 10 .

(50) JÁuregui, CARLos e PiñEIro, José, op. cit., p. 74.

(51) V. a respeito Jáuregui, Carlos e PiÑEIro, José, op. cit., p. 76.

(52) Jáuregui, Carlos e PiñEIro, José, op. cit., p. 76.

(53) Op. cit., p. 76. 
na iủentificação de mercadorias, na repressão de monopólios, sôbre a especulação ilícita, etc., conforme atestam os autores argentinos já tantas vêzes citados.

Como confirmação da influência derrogatória dos princípios clássicos do ciireito penal que a economia dirigida vem consolidando nos últimos tempos, podemos trazer à luz um exemplo colhido em legislação nossa: o Decreto n. ${ }^{0} 14.728$, de $16 / 3 / 1921$, que aprovou o Regulamento para a Fiscalização dos Bancos e Casas Bancárias, estatui no seu art. 74 que "quaisquer indivíduos ou pessoas jurídicas, que praticarem cperações proibidas neste regulamento ou pelo inspetor de bancos, serão punidos com a mesma penalidade aplicada aos bancos e casas bancárias". JAYME LEONEL diz que "istc, entretanto, não significa nenhum desrespeito ao princípio da personalidade da pena. Há, antes, o implícito reconhecimento de uma espécie de responsabilidade subsidiária, a cargo da pessoa jurídica, como garantia do cumprimento da obrigação penal de que, conforme ncta $M$ AGGIORE - existem antecedentes na Lei italiana n. $^{\circ} 5$, de 7 de janeiro de 1929, sôbre transgiressõos de leis financeiras". (54)

O problema da responsabilidade penal das pessoes jurídicas mais antigo que poderia parecer à primeira vista, foi objeto de largos debates em que se ciefrontaram os mais ilustres representantes da ciência penal de todo o mundo. As sanções preconizadas pelo legislador argentino para casos de especulação ilícita já tinham sido recomendadas em 1929, quando da realização de um Congresso Internacional em Bucareste, em moção que se traduz nas seguintes palavras:

$\left.1^{\circ}\right)$ Que sejam estabelecidas em direito penal interno medidas eficazes de defesa social contra as pessoas morais, quando se trate de infraçōes perpetradas com o fim de satisfazer o interêsse coletivo das mencionadas pesscas ou com os meios fornecidos por elas e que arrastem assim sua responsabilidade.

$2^{\circ} .^{\circ}$ Que a aplicação das medidas de defesa social à pessoa moral não deve excluir a possibilidade de uma responsabilidade penal individual para a mesma infração, das pessoas físicas, que têm a administração ou a direção de interêsses de pessoal moral, ou que cometeram a infração com os meios tornecidos pela pessoa moral". (55)

Era, pcis, o reconhecimento de uma solidariedade penal das pessoas jurídicas, como entes ideais, com as pessoas físicas, seus representantes, na consumação de um mesmo delito.

Pode diferir a modalidade da pena, mas isto não constitui novidade, porque seriam de acôrdo com a natureza da pessoa jurídica as penas que the teriam de ser infligidas. As penas privativas de liberdade e que condizem com a natureza física do homem, evidentemente não teriam guarida num sistema repressivo em que as sançōes a serem cominedas se dirigem a entes ideais. Mas nada impede que outras sanções penais se apliquem. Por isso, AFONSO ARINOS observa que "Naturalmente que às pessoas jurídicas, dada a suia ausência de organização física, não poderão ser infligidas senão certas

(54) LEONEL JAYME, op. cit.

(55) V. Melo Franco, A. A. DE, op. cit., pp.92-3. 
espécies de penas, compativeis com a responsabilidade e personalidade das mesmas. Penas aflitivas ou pecuniárias, em geral. Multas, suspensão de ativirades, dissoluçōes... (56)

Em consolidação do que viemos afirmando e para que não se arrepiem muito os que ainda se achem apegados aos princípios do individualismo jurídico, provindos de noçōes faliveis como a própria natureza humana, cuilhemos essa afirmação de Afonso ARINos com relação ao nosso Direito: "Ele (57) estabeleceu de modo insofismável, por têrmos precisos e diretos, a responsabilidade das pessoas jurídicas de direito privado que as nossas leis penais, desde 1830 , como vimos, vèm reconhecendo mais ou menos indiretamente, por proposições veladas por referências acidentais". (58)

Como exemplo recente de suspensão de atividades, pena tipicamente de natureza penal e adequadas às pessoas igualmente jurídicas, citamos o art. 11 da Lei n. ${ }^{\circ} 2.145$, de 29/12/1953 (criou a Carteira de Comércio Exterior): prorrogada pelas Leis ns. 2.410 e 2.807 , de $29 / 1 / 55$ e $28 / 6 / 56$, respectivamente:

"Art. 11. Sem prejuízo de outras sanções previstas em lei, e além de incidirem em multas de $\operatorname{Cr} \$ 5.000,00$ a $\operatorname{Cr} \$ 20.000,00$, ficarão impedidos de importar e exportar, por período de seis a doze meses os que por declarações falsas, ou outros processos dolosos, infringirem os preceitos desta lei" (grifo nosso).

\section{JUSTIFICATIVA DO PEDIDO DE ELEVAÇÃO A ILÍCITO PENAL DAS INFRAÇÕES AO CONTRÔLE DE CÂMBIOS}

Chegamos assim ao têrmo final do caminho por onde tivemos de percorrer ao analisar a legislação de câmbios sob o aspecto penal. Vimos que o contrôle de câmbios como instrumento de política econômica, poderoso que é, deve ser tutelado por um sistema de leis eficientes, capazes de, pelo temor que incutam os pessoas, prevenir os abusos e desrespeitos. Se impotentes, é de se lobrigar desde longe a temibilidade dos recalcitrantes, que bem justifica a reação do Estado colhendo-os nas malhas do Direito Penal, como ultima ratio, no dizer de NELSON Hungria, de que lança mão o legislador. Aos solidária e penalmente responsáveis com as pessoas jurídicas, penas privativas de liberdade; àquelas, as condizentes com a sua natureza ideal, até a máxima, isto é, a dissolução.

Sabemos que muitos seriam os óbices, os tropeços e as discussões que a implantação de uma pena de prisão para as violações ao contrôle de câmbios liaveria de levantar.

Aventuramo-nos a escrever êste trabalho animado pelo espírito de colaboração com a opinião pública, como que adormecida diante de infrações ccntra as qua1s os sentimentos de moral média de nosso povo ainda não estão bastante afinados para compreender o vulto dessas violações, a potencialidade dos danos que podem causar à nossa economia, além de, com

(56) MELo Franco, A. A. DE, op. cit., pp. 74-5.

(57) Art. 12 da Lei n. ${ }^{\circ} 4.269$, de 17-1-1921.

(58) Melo Franco, A. A. DE, op. cit., p. 110. 
reiação à integridade, por assim dizer, moral do Estado, assim como à sua funcionalidade, o quanto de desprestígio inegàvelmente acarreta a conduta de firmas e indivíduos inescrupulosos, astutos, engenhosos, capazes de, ardilosamente, urdir e aparatar tôda uma trama com o fim de neutralizar o contrôle do Estado sôbre as divisas que, no fundo e na sua maior parte, representam o resultado da exportação de produtos brasileiros, a cujo valor indissolùvelmente se ligou o trabalho de nosso povo e que melhor fim bem merece do que virem a ser objeto de câmbio negro e de todo o séqüito de malefícios que êste arrasta consigo à coletividade.

O fato de os crimes de direito comum se catalogarem pelo profundo sentimento de repulsa que a conduta delituosa é capaz de permanentemente despertar num determinado grupo social, num povo, por exemplo, não afasta a possibilidade de se tipicar como crịme a infração ao contrôle de câmbios porque êste não seja durađouro.

Para nós êste argumento é falso, tendo em vista a natureza especial da legislação. Não fôsse isto verdade e não veríamos o Estado, intervindo diretamente no jôgo das competições econômicas dos indivíduos, reprimir com penas privativas de liberdade, os atentados à economia popular e outras formas novas de delitos.

O que hoje constitui ilícito punivel ainda administrativamente, poderá amanhã sê-lo por via judicial. "A identidade essencial entre o delito administrativo e o delito penal é atestada pelo fato histórico, aliás, reconhecido por GoLDSHMIDT, de que "existem poucos delitos penais que não tenham passado peì estado de delito administrativo".

A disparidade entre um e outro, repita-se, é apenas quantitativa.

A punição de certos ilícitos na esfera do direito administrativo, ao invés de o ser na órbita do direito penal comum, não obedece, como já frisamos, senão a razões de conveniência política: para o delito penal comum é trans. portado apenas o ilícito administrativo de maior ǵravidade objetiva ou que afeta mais direta e intensamente o interêsse público ou social, passando, assim, a ilícito penal. O ilícito administrativo de menor entidade não reclama a severidade da pena criminal". (59)

\section{O EXEMPLO DE OUTROS POVOS}

Em apoio da sugestão que damos neste trabalho, devemos acrescentar que, na Alemanha, na Argentina, na Âustria, na Bulgária, no Canadá, no Chile, na Dinamarca, no Egito, na França, para citarmos países de reconhecida consciência jurídica evoluída, as infrações à regulamentação dos câmbios constituem crimes puníveis com as penas privativas de liberdade, sem prejuizo das sanções de caráter administrativo.

Se estas minhas considerações encontrarem eco na consciência jurídica de nosso povo, damo-nos por satisfeito em ver que o Estado não pode permanecer complacente com a atitude hostil dos que, ferindo as suas leis, contribuem para a verificação de desigualdades que a evolução dos tempos

(59) Hungria, Nelson, apud Leonel JAyme, op. cit., pp. 55-56. 
nos obriga a dissipar. Se não, aqui fica um protesto sereno contra aquêles qua, ideal ou fisicamente constituídos, não se encontram moralmente dotados para viverem em comum com os seus pares, por não pretenderem satisfazer as minimas exigências éticas do meio ambiente, nem tampouco comungam os mesmos ideais.

Entre nós, a par das multas, do seqüestro dos valores e fundos, e impedimentos de exercer as atividades por determinada época, vimos que nada além existe para punir as infrações à regulamentação cambial. A multa, enquanto noutros países de contrôle de câmbios como o nosso, atinge o décuplo do valor da operação, nós a cominamos apenas no valor do dôbro para os casos de operações de câmbio ilegítimas, de acôrdo com o art. $6 .^{\circ}$, do Decreto número 23.258 , de $19 / 1 / 1933 ! ! !$

"Dia virá, diz Jُ4YMe LEONEL, e talvez não tarde muito, que uma legislação mais severa venha a substituir cs textos vigorantes, positivamente desajustados e desatualizados, para adotar outros meios de reação, mais próprios e mais identificados com a realidade do mundo contemporâneo". (60)

$E^{\prime}$ um justo anseio que deveria generalizar-se.

(60) LeONel JAYMe, op. cit., p. 83. 